\title{
SIMULATION OF THE INFLUENCE OF VEGETATION ON MICROCLIMATE AND THERMAL COMFORT IN THE CITY OF SÃO PAULO
}

\author{
Jörg Spangenberg ${ }^{1}$, Paula Shinzato $^{2}$, Erik Johansson $^{3}$ and Denise Duarte ${ }^{4}$
}

(recebido em 29.11.2007 e aceito para publicação em 18.04.2008)

\begin{abstract}
The microclimates of a park, a square and a street canyon were measured on a summer day in the city centre of São Paulo, Brazil. The field monitoring showed that the park was up to $2^{\circ} \mathrm{C}$ cooler than the square and the canyon. The effect of adding shading trees to the street canyon was simulated for the same day using the numerical model ENVI-met. The simulations showed that incorporating street trees in the urban canyon had a limited cooling effect on the air temperature (up to $1.1^{\circ} \mathrm{C}$ ), but led to a significant cooling of the street surface (up to $12^{\circ} \mathrm{C}$ ) as well as a great reduction of the mean radiant temperature at pedestrian height (up to $24^{\circ} \mathrm{C}$ ). Although the trees lowered the wind speed up to $45 \%$ of the maximum values, the thermal comfort was improved considerably as the physiologically equivalent temperature (PET) was reduced by up to $12^{\circ} \mathrm{C}$.
\end{abstract}

Keywords: urban vegetation, urban microclimate, numerical simulation, pedestrian thermal comfort.

\footnotetext{
${ }^{1}$ Arquiteto, doutorando da Bauhaus University, Weimar, Germany, e do Laboratório de Conforto Ambiental e Eficiência Energética (LABAUT), FAUUSP, São Paulo-SP, joerg_spangenberg@yahoo.com.br

${ }^{2}$ Arquiteta, mestranda, bolsista FAPESP, LABAUT, FAUUSP, São Paulo-SP, paulashinzato@yahoo.com

${ }^{3}$ Engenheiro Civil, Dr., Housing Development \& Management, Lund University, Sweden e pós-doutorando LABAUT, FAUUSP, São Paulo-SP, erik.johansson@hdm.lth.se

${ }^{4}$ Profa. Dra., LABAUT, FAUUSP, São Paulo-SP, dhduarte@terra.com.br
} 


\section{SIMULAÇÃO DA INFLUÊNCIA DA VEGETAÇÃO NO MICROCLIMA URBANO E CONFORTO TÉRMICO NA CIDADE DE SÃO PAULO}

\section{RESUMO}

Durante o verão, foram realizadas medições das condições microclimáticas existentes em um parque, uma praça aberta e um canyon urbano na cidade de São Paulo. Os resultados do monitoramento de campo indicaram que o parque apresenta temperaturas do ar até $2^{\circ} \mathrm{C}$ mais baixas do que na praça e no canyon. O efeito de novas árvores no canyon urbano foi simulado por meio do modelo ENVI-met na mesma data da medição. Os resultados das simulações mostram o efeito do resfriamento da temperatura do ar em até $1.1^{\circ} \mathrm{C}$ e, por outro lado, uma diminuição da temperatura superficial do pavimento (até $12^{\circ} \mathrm{C}$ ), bem como uma considerável redução na temperatura radiante média no nível do pedestre (até $24^{\circ} \mathrm{C}$ ). Apesar da diminuição da velocidade do vento em até $45 \%$ nos valores máximos, o conforto térmico teve uma melhora considerável, uma vez que a temperatura fisiológica equivalente (PET) foi reduzida em até $12^{\circ} \mathrm{C}$.

Palavras-chave: vegetação urbana, microclima urbano, simulação numérica, conforto térmico dos pedestres. 


\section{INTRODUCTION}

In the tropics, the outdoor thermal comfort conditions during daytime are often far above acceptable comfort standards due to intense solar radiation and high solar elevations (Ali-Toudert and Mayer, 2007; Johansson, 2006). While the urban heat island is less of a problem in temperate climates, it is unwanted in low and mid latitude cities as it contributes to increase the cooling load and results in increased energy use (Taha, 1997).

Vegetation is an important design element in improving urban microclimate and outdoor thermal comfort in urban spaces in hot climates (Spangenberg, 2004). Due to urbanization, however, vegetation is scarce in many tropical cities. There has often been a tendency to replace natural vegetation and permeable soils with impervious surfaces such as asphalt and concrete, which leads to more sensible than latent heat flux (Emmanuel, 2005). In urban streets, vegetation is often considered a problem for several reasons. For example, trees are costly to maintain, their canopies often interfere with overhead telephone and electric lines and their roots may destroy pavements and underground sewers.

\section{The use of vegetation in hot climates}

The main benefits of vegetation in hot climates are reduced solar radiation and lower air temperature due to shading and evapotranspiration. Lower air temperatures are essential both to improve thermal comfort conditions of pedestrians and to limit energy use for cooling. According to Akbari et al. (2001) peak energy demand in the USA rises $2-4 \%$ for every $1^{\circ} \mathrm{C}$ increase in maximum air temperature.

Among other factors, the effect of vegetation on the microclimate depends on the size of the vegetated area. While the cooling effect on the air temperature is limited for a single tree or a small group of street trees (Oke, 1989), larger areas such as parks can have a significant cooling effect ( $\mathrm{Yu}$ and Hien, 2006). The evapotranspiration of vegetated areas is highly dependant on soil humidity; for dry soils, which are common in urban areas due to sealing of the ground, evapotranspiration cooling will be limited (Oke, 1989).

There are also negative effects of vegetation in warm climates. One drawback with trees is that they block the wind; a deciduous tree may reduce wind speeds by $30-40 \%$ (AliToudert and Mayer, 2007). Trees with large canopies will also reduce nocturnal cooling as they block some of the net outgoing long-wave radiation.

Several recent studies have shown that vegetation is beneficial in lowering air temperatures, in providing shade and in improving thermal comfort. Field measurements by Shashua-Bar and Hoffman (2004) showed that some tree-aligned streets and boulevards in the Tel-Aviv area, Israel, had $1-2.5^{\circ} \mathrm{C}$ lower air temperatures than non-vegetated streets at 
the hottest part of the day $(15: 00 \mathrm{~h})$. Applying the simulation software ENVI-met (Bruse, 2006) to the climate of Thessaloniki, Greece, Chatzidimitriou et al. (2005) found small temperature decrease for tree-aligned streets (less than $1^{\circ} \mathrm{C}$ ), but up to $20^{\circ} \mathrm{C}$ lower surface temperatures and more than $40^{\circ} \mathrm{C}$ lower mean radiant temperatures. The cooling effect was found to increase with rising number of trees. In the hot dry climate of Ghardaia, Algeria, AliToudert and Mayer (2007) found that shading trees could improve the thermal comfort in streets considerably. In another simulation study of different greening scenarios using ENVImet in Rio de Janeiro, Brazil, Spangenberg (2004) found that an increased amount of urban green (tree cover of $30 \%$ of the ground and $100 \%$ green roofs) could nearly re-create the comfortable conditions of a natural forest.

\section{Urban vegetation in São Paulo, Brazil}

This paper shows preliminary results from an ongoing study of the benefits of vegetation in the city of São Paulo, Brazil. The research includes field measurements during the hot humid summer to compare the microclimates of a park, a square and an urban canyon as well as numerical simulations of the effect of vegetation on microclimate using ENVI-met (Bruse, 2006). There are several recent studies simulating the effect of vegetation in warm climates with ENVI-met. These studies have, however, been either focussing on air temperature in warm and dry climates (Ali-Toudert and Mayer, 2005; Ali-Toudert and Mayer, 2007; Chatzidimitriou et al., 2005) or only treated effects on the air temperature and not thermal comfort itself (Jusuf et al., 2006; Spangenberg, 2004; Yu and Hien, 2006).

The objective of this research is to study the effect of shading trees with different leaf densities on the microclimate and outdoor thermal comfort in public spaces. From the output data provided by ENVI-met it is possible to estimate thermal comfort by calculating the Physiologically Equivalent Temperature (PET).

\section{MATERIALS AND METHODS}

\section{Area of Study}

The city of São Paulo

The city of São Paulo is located at $23^{\circ} 32^{\prime} \mathrm{S}, 46^{\circ} 37^{\prime} \mathrm{W}, 60 \mathrm{~km}$ from the sea. The altitude varies between $720 \mathrm{~m}$ and $850 \mathrm{~m}$. The city's climate is characterised by hot, humid summers with air temperatures varying between mean minima of $22^{\circ} \mathrm{C}$ and mean maxima of $30^{\circ} \mathrm{C}$ and mild winters with temperatures between mean minima of $10^{\circ} \mathrm{C}$ and mean maxima of $22^{\circ} \mathrm{C}$. 
São Paulo is a sprawling South American megacity, which's metropolitan area houses almost 19 million inhabitants, distributed in an area of $8051 \mathrm{~km}^{2}$. Based on reports from the Municipal Environmental Agency (SVMA, 2004), São Paulo's economy represents $31 \%$ of the national Gross Domestic Product (GDP). However, this economic development has led to a significant degradation of the urban environment, a common situation in many large cities in developing countries.

Today, São Paulo is characterised by a heterogeneous urban structure, which has been caused by the rapid growth of the city during the last century. One of the effects of this growth is the social conflict and contrast of high-rise office towers close to poor informal settlements (favelas). According to the architect Oscar Niemeyer, "The first lesson São Paulo offers is that no city should grow so arbitrarily" and "the second lesson of São Paulo is that its people, and the people of cities in poor countries elsewhere, should have the right to a habitat that is more graceful" (Romero, 2000).

The distribution of vegetated areas is non-uniform in the city. Only the wealthiest boroughs are characterised by large amount of vegetation and tree-aligned streets, while the downtown areas of Brás and Santa Cecília are almost devoid of vegetation (SVMA, 2004). The Environmental Atlas of São Paulo (SVMA, 2004) includes a map showing surface temperatures in the city of São Paulo. The highest temperatures were found in the central area without green areas and the lowest in urban parks. Similar temperature patterns were found by Duarte and Souza (2005).

To improve the situation, the City Hall is investing in tree planting programs and several linear parks, intending to increase the vegetated areas.

\section{On-site Measurements}

The central area of São Paulo is formed by the Old Town (Sé), the New Town (República) and another 10 boroughs (Meyer et al., 2004). In the downtown area, there are seven urban parks.

For decades, downtown has suffered a continuous degradation process and has gradually been abandoned by its residents. The metropolitan area of São Paulo experiences simultaneously massive urban sprawl in its peripheries and population decrease in its central parts (the population of the central borough of República diminished by $28 \%$ between 1980 and 1999). Today, some downtown districts have a population density of less than 70 inhab/ha (IBGE, 2000) in spite of a high built density.

To change this negative trend, downtown has been the focus of revitalization efforts with several urban projects organized by the local government. The recent initiatives show the special interest to promote a public discussion for possible transformations of the existing urban structure. One of them is the project Nova Luz (New Luz), which intends to implement 
new commercial and residential buildings on the one hand and preserve the existing architectural patrimony on the other hand. However, vegetation does not play a major role in this renewal process.

This study focuses on the area of Luz (Figs. 1 and 2), which is situated in the city centre.
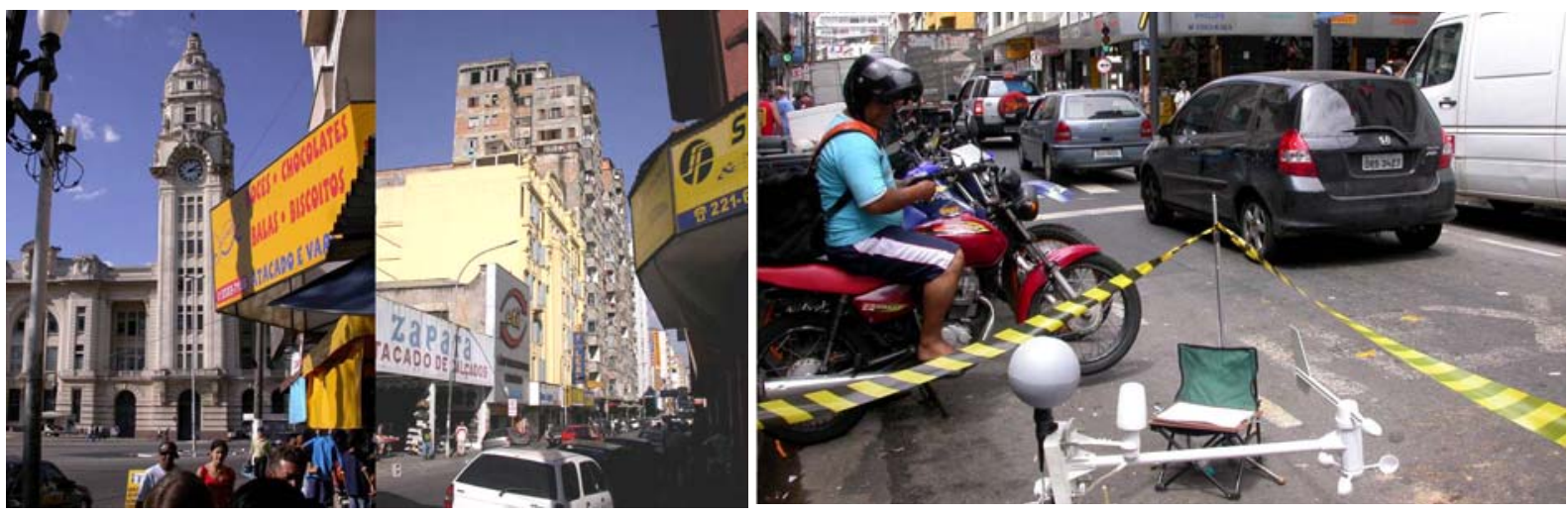

FIGURE 1. a) Street life in the Luz area (photos of square, left, and street canyon, right).

b) The measurement equipment used in the urban canyon. Source: LABAUT

Since 2004, LABAUT has been studying the central area of the city as part of a partnership with University of Cambridge and University of East London (LABAUT, 2006). The project Sustainable Urban Spaces has explored new environmental approaches for the revitalization of abandoned parts in central areas.

\section{Methodology}

\section{On-site Measurements}

Climate monitoring was carried out on $19^{\text {th }}$ of December 2006 in the area of Luz (Figs. 1 and 2). This day can be considered a typical hot summer day: clear sky conditions in the morning, partly overcast sky in the afternoon and rain in the evening (see Fig. 4). The main goal of these measurements was to create an initial database for air temperature, relative humidity, solar radiation, surface temperature, wind direction and wind speed for the summer period.

Three main types of urban spaces were defined for the measurements: a park, an open air square and an urban canyon. These three areas were chosen considering the main characteristics of the site and its surroundings (Fig. 2). The particular interest was to compare the effect of vegetation in the park with the other two situations. The sky view factor, that is, the amount of the sky seen from a point on the ground, of the three sites varies considerably (Fig. 3). 


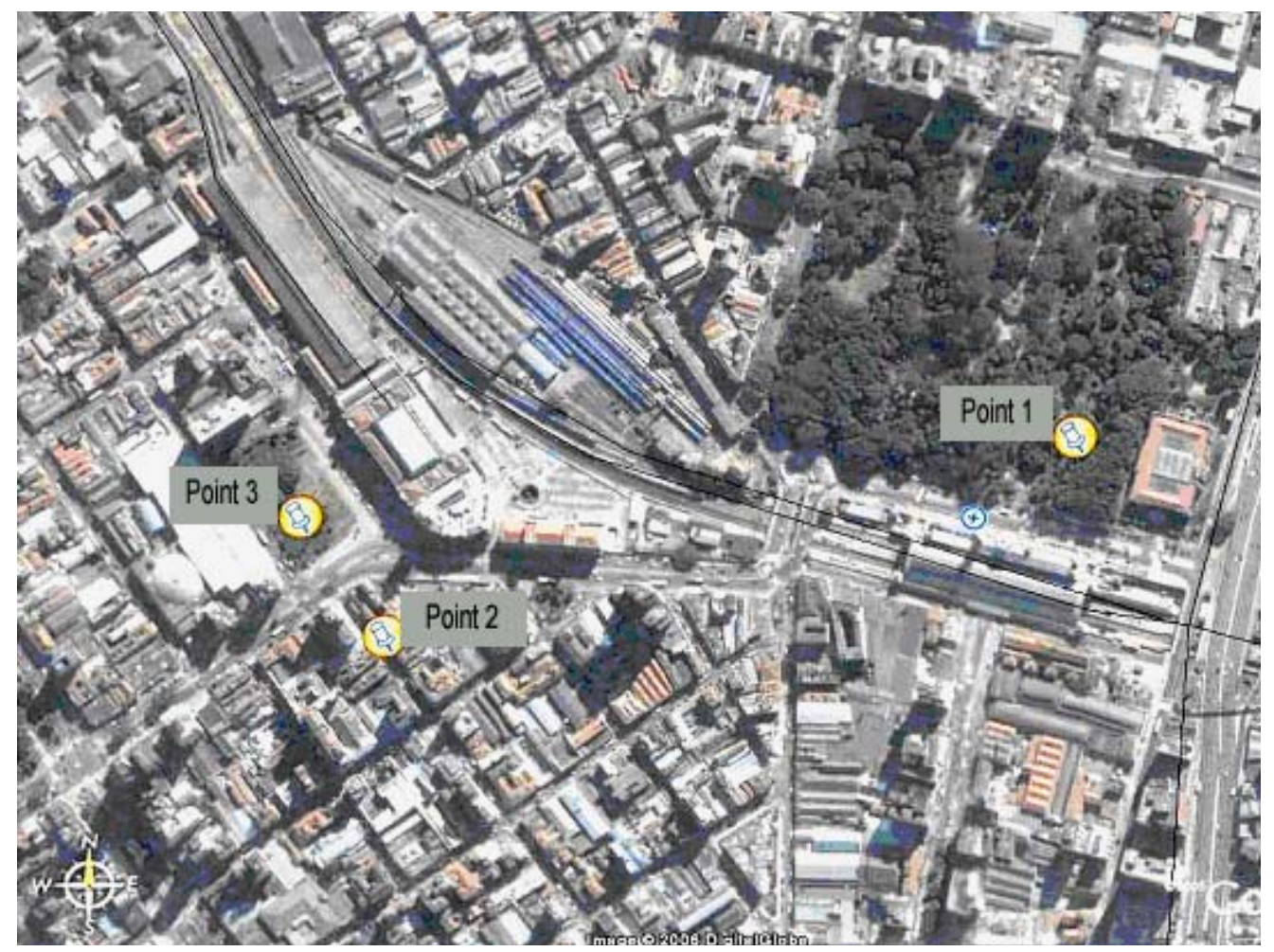

FIGURE 2. Location of the three measurement points in Luz borough.

Point 1 = park, point 2 = canyon and point $3=$ square. Source: Google Earth

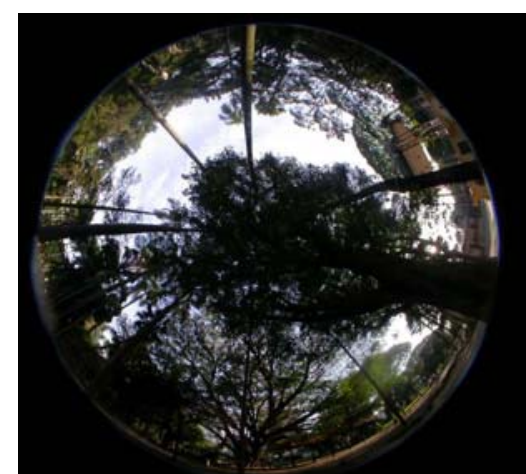

(1)

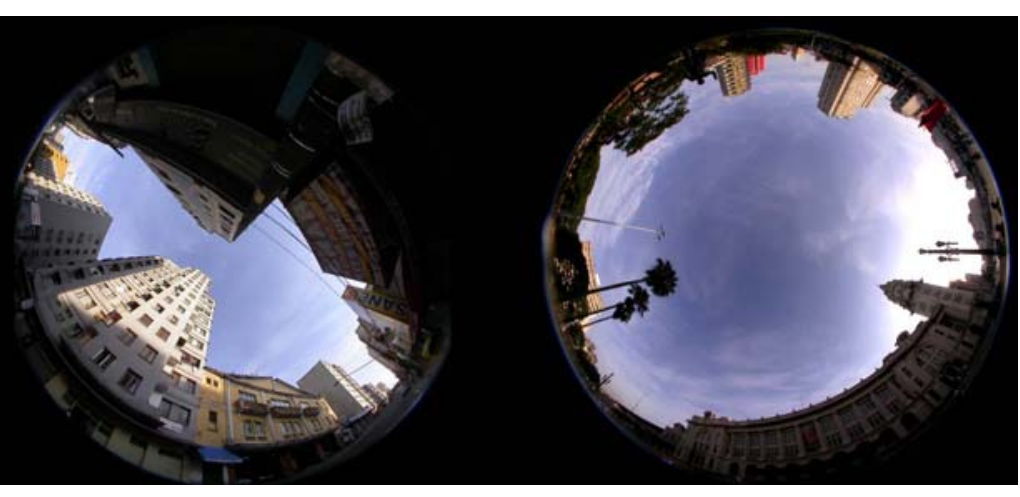

(2)

(3)

FIGURE 3. Hemispheric pictures of the sky view taken with a Nikon 4500 equipped with a $180^{\circ}$ fish eye lens for park (1), canyon (2) and open square (3). Source: LABAUT

The canyon is located in a dense area with 5-10 storeys high commercial buildings. The street has an intense flux of vehicles and pedestrians attracted by the local commerce of electro-electronics devices (Fig. 1a). In addition to this critical situation, the thermal comfort is 
poor. The average block size in Luz is $60 \mathrm{~m}$ by $100 \mathrm{~m}$. The street canyon has an average width of $12 \mathrm{~m}$ and the building height is on average $26 \mathrm{~m}$ (corresponding to eight-storey buildings) which gives a height to width ratio $(\mathrm{H} / \mathrm{W})$ of 0.5 . There are very few trees in the street due to narrow sidewalks and problems with aerial electric cables and telephone lines. The open square, which has white stone paving (Portuguese pavement), is more exposed to direct solar radiation than the other sites due to lack of vegetation and shading.

Three meteorological stations (Huger WM 918 and 968, as well as ELE MM900) were used to measure air temperature, humidity and wind speed simultaneously at $1.10 \mathrm{~m}$ height at the three locations (Fig. 1b). All measurements were recorded on data loggers every ten minutes between 7:00 and 19:00 local daylight saving/ summer time.

On the square, additionally global solar radiation was measured with a pyranometer. Surface temperatures of various construction materials and natural surfaces were measured on the square using an infrared thermometer TFA 31.1108. During the intervals of the measurements interviews with pedestrians regarding their thermal comfort sensation and their opinion on benefits and problems with vegetation in the city were carried out.

\section{Thermal Comfort Surveys}

To support a study aiming at developing a local comfort index for São Paulo, surveys on the subjectively perceived outdoor thermal comfort were executed in the three aforementioned locations. Since this study is not concluded yet, the Physiologically Equivalent Temperature (PET, Höppe, 1999) was adopted in this paper to evaluate and compare the results. PET, which is designed for outdoor conditions and is based on a steady-state heat balance equation of the human body, takes all environmental parameters that affect thermal comfort - air temperature, mean radiant temperature, humidity and wind speed - into account. Personal factors such as clothing insulation and the level of activity are, however, not included. PET has recently been calibrated against subjective comfort votes in the climate of São Paulo by Monteiro and Alucci (2006) who interviewed approximately 2.000 people adapted to local conditions.

\section{Microclimate simulations}

The micro scale model ENVI-met (Bruse, 2006) was chosen for this study due to its advanced approach on plant-atmosphere interactions in cities. The numerical model simulates aerodynamics, thermodynamics and the radiation balance in complex urban structures with resolutions (grid-sizes) between $0.5 \mathrm{~m}$ and $10.0 \mathrm{~m}$ according to position of the sun, urban geometry, vegetation, soils and various construction materials by solving thermodynamic and plant physiological equations. 
The building section of the model has shown some limitations, since the same properties (such as albedo and U-value) are applied equally to all walls and roofs respectively. Further, the heat storage term for the buildings, which calculates the time lag, is not included in the energy balance of the building surfaces. Due to this fact, the thermal mass of vertical constructions, which causes delayed heat dissipation, is not taken into account for buildings, as it is for ground paving and soils.

The input data for the simulations are shown in Table 1 and the input area file is shown in Fig. 4a. The solar radiation, which is calculated depending on latitude, was slightly over-estimated by ENVI-met for São Paulo conditions and was therefore decreased to 90\%. The only additional climate data (not derived from local measurements) was that for specific humidity at $2500 \mathrm{~m}$, which was obtained from local airport soundings at Campo de Marte (ca. $3.3 \mathrm{~km}$ North of the site), available from the homepage of University of Wyoming (UWYO, 2007).

As recommended (Bruse, 2006), 48 hours simulations were used to pass the initial transient time in order to obtain results that are more reliable. In the preliminary simulations, both the average air temperature and the diurnal amplitude were underestimated. Therefore, some of the input data had to be adjusted to achieve better correlation with the measured results. The temperature course of the model has shown significant sensibility to wind speed. The diurnal amplitude tends to increase with decreased wind speed. The measured wind speed varied strongly in direction and speed throughout the day. The average mean wind speed measured was $1.6 \mathrm{~m} / \mathrm{s}$, but $0.8 \mathrm{~m} / \mathrm{s}$ was adopted in order to adjust the temperature curve. The initial temperature was increased by $1^{\circ} \mathrm{C}$ in order to approximate to measured peak values, resulting in a limited correlation between measured and simulated temperature curve in the morning (7:00 - 9:00 h) and in the evening (17:00 - 20:00 h). 
TABLE 1. Input configuration data applied in the ENVI-met simulations.

\begin{tabular}{|l|c|}
\hline Atmosphere & $7: 00$ \\
\hline Start of simulation (h) & 0.8 \\
\hline Wind speed at $10 \mathrm{~m}$ above ground level [m/s] & 170 \\
\hline Wind direction & 297 \\
\hline Initial temperature of the atmosphere [in degrees Kelvin] & 9.0 \\
\hline Specific humidity at 2500 m [g Water/kg air] & 0.9 \\
\hline Solar adjustment factor & 70 \\
\hline Relative humidity at 2m [\%] & \\
\hline Soils & 25 \\
\hline Relative humidity in all layers [\%] & \\
\hline Buildings & 0.4 \\
\hline Albedo of walls & 0.3 \\
\hline Albedo of roofs & \\
\hline
\end{tabular}

After the calibration process, similar daily temperature and humidity curves were achieved. The comparison between measured and simulated air temperature is shown in Fig. 4b. The calculated coefficient of determination, $\mathrm{R}^{2}$, between measured and simulated air temperature, based on 79 values, was found to be 0.7487 .
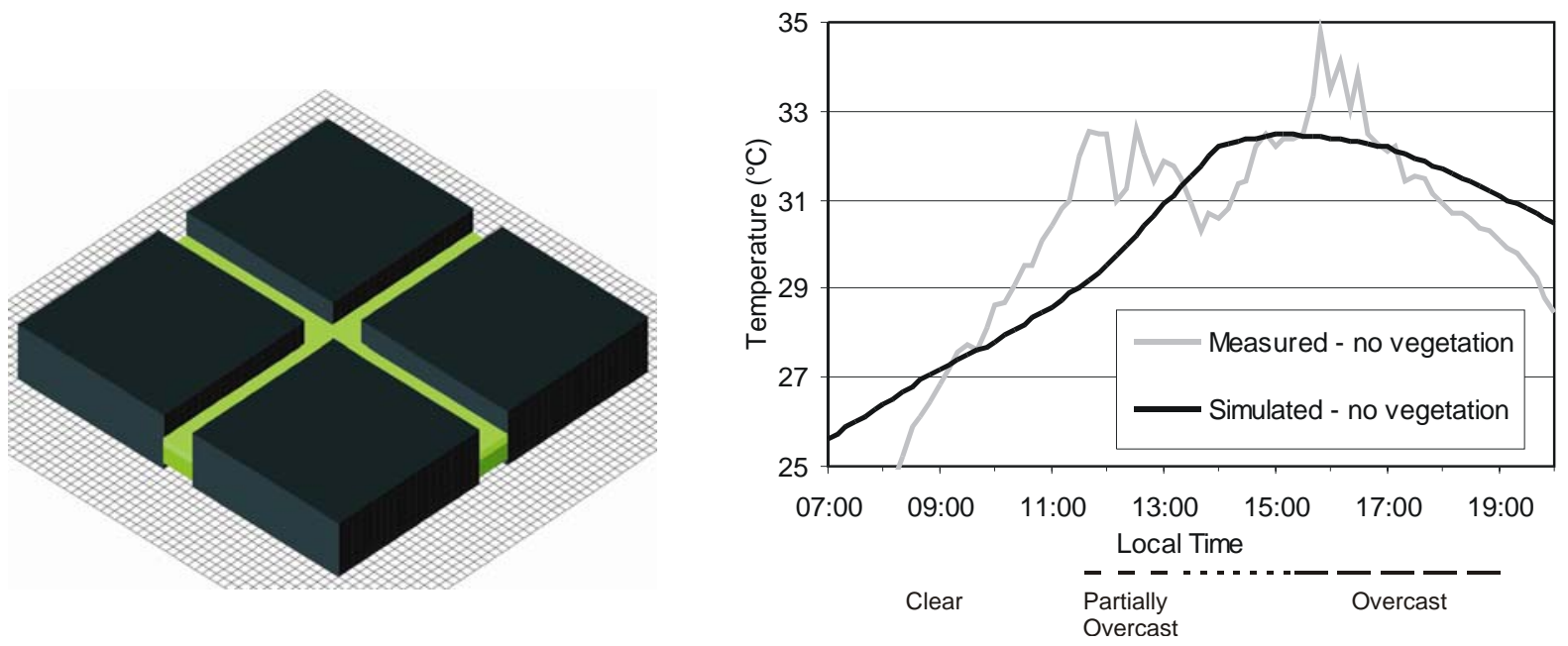

FIGURE 4. a) Input area domain for simulations with trees (including nesting area). b) Comparison between measured and simulated air temperature for the existing street canyon. The changing sky conditions shown in the figure refer only to the measured data and cannot be simulated with ENVI-met yet. 
To a large extent the urban geometry of a city is characterized by a repetitive element called the urban canyon (Emmanuel, 2005). Consequently, an urban canyon was chosen for a parametric study and the simplified model is shown in Fig. 4a. In addition to the actual situation, two different greening scenarios were simulated, one with less dense street trees (T1) and another with a much denser tree canopy (T2). The leaf area indices (LAI) ${ }^{1}$ for T1 and T2 were $1 \mathrm{~m}^{2} / \mathrm{m}^{2}$ and $5 \mathrm{~m}^{2} / \mathrm{m}^{2}$ respectively. Both tree types were $10 \mathrm{~m}$ high with canopies covering the entire street. Both parametric tree models had ellipsoid leaf area distributions with maximum Leaf Area Densities $(L A D)^{2}$ located in the middle of the crowns. The attenuation of solar radiation at midday was $39,3 \%$ for T1 and $91.9 \%$ for T2. The aim was to evaluate how the attenuation of solar radiation of the two tree canopy types influenced air temperature, surface temperature, humidity, wind speed and thermal comfort.
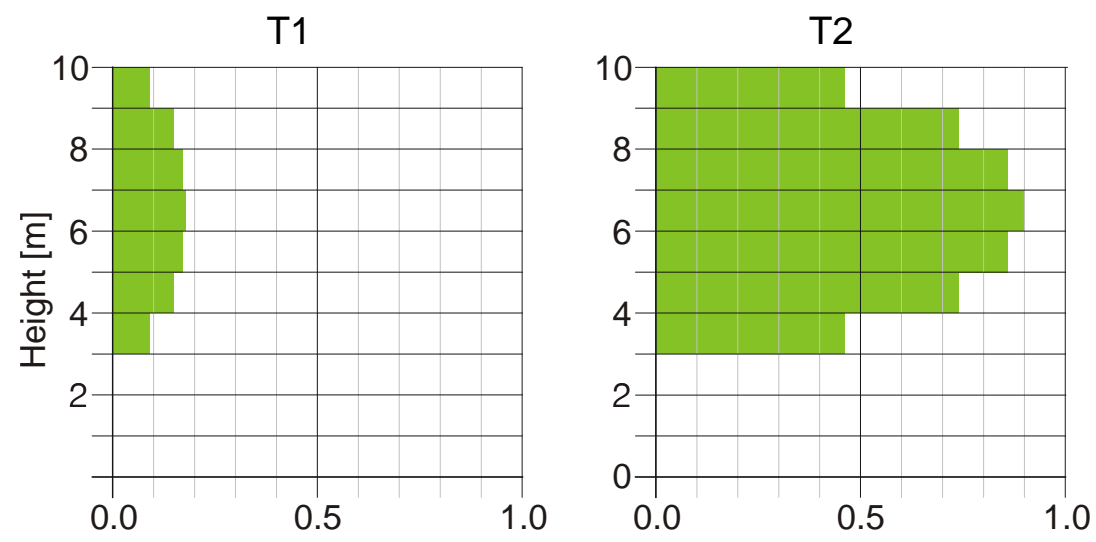

FIGURE 5. LAD (Leaf Area Density) $\left(\mathrm{m}^{2} / \mathrm{m}^{3}\right)$ in 10 layers of the two tree models T1 and T2. T1 has $20 \%$ of the Leaf Area Density (LAD) of T2.

\section{RESULTS AND DISCUSSION}

\section{Measurement Results}

The results shown at Local Time (in this case equal to daylight saving time) of the measurements gave important information about the microclimatic differences among the three urban sites (Fig. 6a). The ambient air temperature profiles show that the cooling effect of the park is on average $2^{\circ} \mathrm{C}$ compared to the open square with peaks up to $6^{\circ} \mathrm{C}$. Compared to the canyon, the temperature of the park is about $2.5^{\circ} \mathrm{C}$ lower around noon. The relative humidity was about $10 \%$ higher in the park than in the other two sites (Fig. 6b). The absolute

\footnotetext{
${ }^{1}$ The Leaf Area Index (LAI) is defined as the total one-sided leaf surface area $\left(\mathrm{m}^{2}\right)$ per unit ground area $\left(\mathrm{m}^{2}\right)$

${ }^{2}$ The Leaf Area Density (LAD) is defined as the total one-sided leaf area $\left(\mathrm{m}^{2}\right)$ per unit layer volume $\left(\mathrm{m}^{3}\right)$ in each horizontal layer of the tree crown.
} 
humidity $\left(\mathrm{g} / \mathrm{m}^{3}\right)$ is about $1 \mathrm{~g} / \mathrm{m}^{3}$ higher in the park. The lower temperature and higher humidity in the park is due to shading and evapotranspiration.
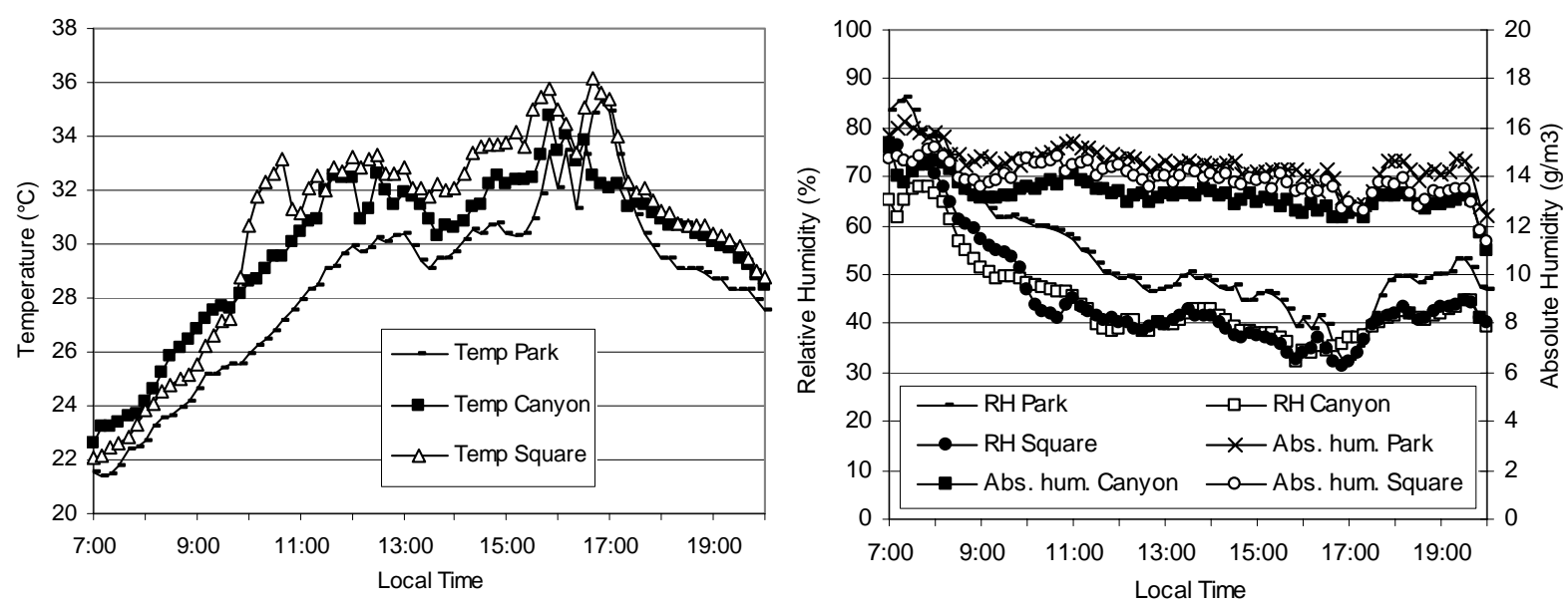

FIGURE 6. a) Results of air temperature distribution for the park, the open square and the canyon. b) Results of relative and absolute humidity distribution for the park, the open square and the canyon.

\section{Simulation Results}

The results are shown for a point in the crossing between the east-west and northsouth oriented street canyons. All results are shown at Local Time, which in our case is equal to daylight saving time (summer time), that is LST+1 h.

\section{Air temperatures}

In Fig. $7 \mathrm{a}$ the simulated air temperature is shown for the three cases no trees, trees having a high-density canopy ( $\mathrm{LAl}=5)$ and trees having a low-density canopy $(\mathrm{LAI}=1)$. The canyons covered with less dense (T1) and dense tree canopies (T2) have, on average, $0.5^{\circ} \mathrm{C}$ and $1.1^{\circ} \mathrm{C}$ lower air temperatures than the case without tree, respectively.

The fact that street trees have only a limited cooling effect on the air temperature agree fairly well with both field measurements (Shashua-Bar and Hoffman, 2004) and simulation studies (Ali-Toudert and Mayer, 2005; Ali-Toudert and Mayer, 2007; Chatzidimitriou et al., 2005). The effect found in this study is, however, less than that reported by Ali-Toudert and Mayer (2005; 2007), who found cooling effects of up to $1.5^{\circ} \mathrm{C}$ for a hot-dry city. The reason may be that the air was dryer in their study and hence the cooling effect of evapotranspiration higher. 

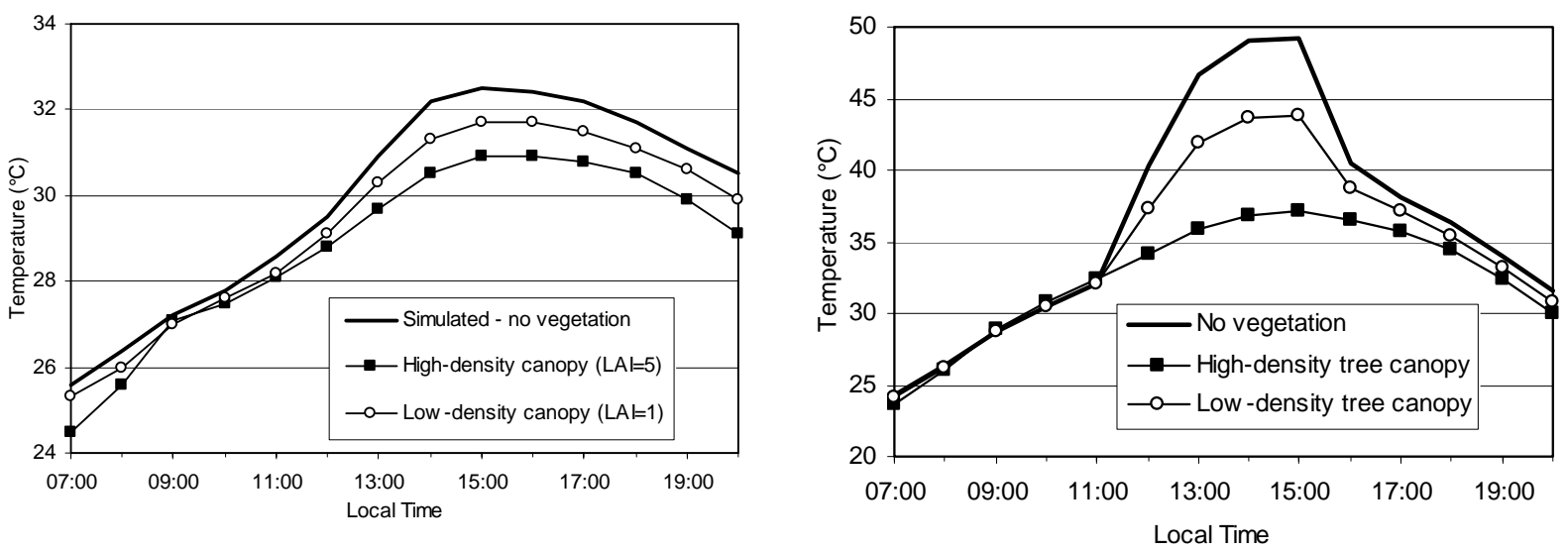

FIGURE 7. a) Simulated air temperature for the street canyon without trees, with trees having a high-density canopy and with trees having a low-density canopy. b) Simulated street surface temperature for treeless street, street with high-density tree canopies and street with low-density tree canopies.

\section{Surface temperatures}

Fig. $7 \mathrm{~b}$ shows the surface temperature of the asphalted street for the three cases (no trees, low-density canopy and high-density canopy). During the hours when the street receives solar radiation (from 12:00 to 15:00), Fig. $7 \mathrm{~b}$ shows that the trees have a huge impact on the surface temperature of the ground. The less dense tree (T1) lowers the temperature by up to $5^{\circ} \mathrm{C}$ and the high-density tree (T2) by up to $12^{\circ} \mathrm{C}$.

The results agree well with Chatzidimitriou et al. (2005), although they report even higher reduction in surface temperatures. The reason may be that they studied a shallower canyon $(\mathrm{H} / \mathrm{W}=0.5)$ and thus the temperature of their treeless case was higher than in this study where the canyon is relatively deep $(\mathrm{H} / \mathrm{W}=2.2)$.

\section{Mean Radiant Temperature (MRT)}

The mean radiant temperature (MRT) is the parameter mostly affected by shading trees. Fig. 8a shows how the MRT varies at pedestrian height for the three cases (no trees, high-density canopy and low-density canopy). During the hours when the street receives solar radiation (from 12:00 to 15:00), Fig. 8a shows that the less dense (T1) and dense (T2) tree canopies lower the MRT by up to $11^{\circ} \mathrm{C}$ and $24^{\circ} \mathrm{C}$ respectively. The high-density canopy is considerably more efficient than the low-density canopy.

The reduction in MRT through shading includes both less received direct, diffuse and reflected short-wave radiation from the sun and lower surface temperatures and thereby lower thermal (long-wave) radiation from urban surfaces. 
The reductions in MRT found in this study are less than found by Chatzidimitriou et al. (Chatzidimitriou et al., 2005). A probable reason is that they studied a shallower canyon as discussed above.

\section{Humidity}

The relative humidity rises only slightly due to the incorporation of trees in the street canyon (less than 5\%). The high-density canopy causes a few per cent higher $\mathrm{RH}$ than the low-density canopy. The absolute humidity is, however, similar for all cases and very stable, varying from about 12 to $14 \mathrm{~g} / \mathrm{m}^{3}$ during the day. The insignificant effect on tree evaporation on humidity found here agrees well with other studies (Ali-Toudert and Mayer, 2005; AliToudert and Mayer, 2007).

\section{Wind speed}

The wind speed simulated by ENVI-met is clearly affected by the trees. Although the studied trees have no leaves between ground level and $3 \mathrm{~m}$ height, the wind speed at pedestrian height $(1.5 \mathrm{~m}$ ) is reduced from about $0.86 \mathrm{~m} / \mathrm{s}$ (no trees) to about $0.80 \mathrm{~m} / \mathrm{s}$ (highdensity canopy) and to $0.47 \mathrm{~m} / \mathrm{s}$ (low-density canopy), respectively. Thus, canopies with low LADs reduce wind speed considerably less than trees with high LADs.
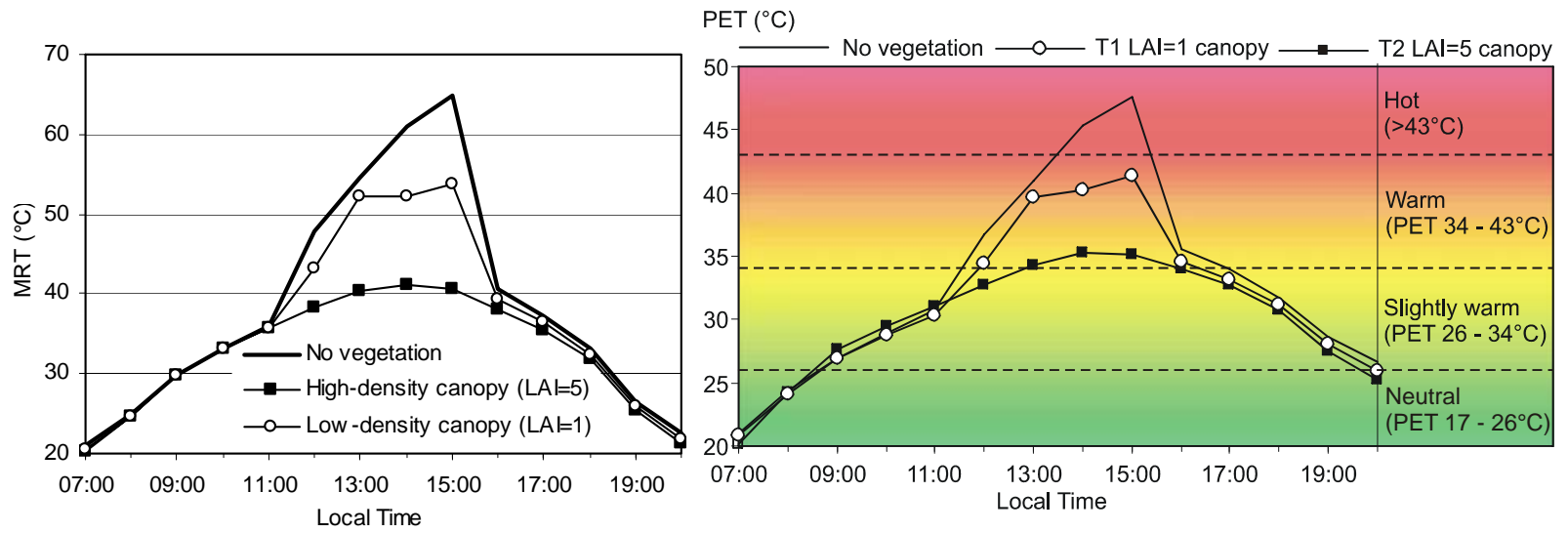

FIGURE 8. a) Simulated MRT for treeless street, street with high-density tree canopies and street with low-density tree canopies. b) Simulated PET for treeless street, street with highdensity tree canopies and street with low-density tree canopies.

\section{Physiologically Equivalent Temperature (PET)}

The thermal comfort, expressed as the physiologically equivalent temperature (PET), was calculated based on simulated values of air temperature, MRT, relative humidity and wind speed (however, the simulated wind speed was increased again to agree with the measurements). 
PET varies significantly between a treeless street canyon and a street covered with tree canopies. Figure 8b shows how PET varies at pedestrian height for the three cases (no trees, high-density canopy and low-density canopy). Similarly to the MRT, PET reaches highly uncomfortable values between $12: 00$ and $15: 00$. This peak is considerably lowered by the less dense trees (T1) and virtually erased by the dense shading trees (T2). Denser trees are thus more efficient although they lower the wind speed more than the less dense trees.

The reductions in PET found in this study (up to $12^{\circ} \mathrm{C}$ ) are less than those presented by Ali-Toudert and Mayer (Ali-Toudert and Mayer, 2005; Ali-Toudert and Mayer, 2007) who found reductions above $20^{\circ} \mathrm{C}$. The reason may be that they had a larger proportion of direct solar radiation and thus the trees provided more efficient shade.

\section{CONCLUSIONS}

The measurements indicated that the public Luz Park has a cooling effect with around $2^{\circ} \mathrm{C}$ lower temperatures than its surroundings. The surface temperature measurements also showed that natural surfaces are considerably cooler than commonly used construction materials such as concrete and asphalt.

The results from the simulations presented in this study clearly show that vegetation in the form of trees has a great potential of improving the microclimate and mitigate heat stress in a hot humid climate.

The leaf area index (LAI) and leaf area density (LAD) of the canopy proved to be important metrics, which have a significant influence on the microclimate. The denser the tree canopy (higher LAI and LAD), the lower the air and surface temperatures and the better the thermal comfort for hot-humid climate.

In general, trees provide, under their canopies (locally restricted), significant improvements on thermal comfort principally during midday and in the early afternoon as they provide overhead shading by attenuating the solar radiation. The crucial benefit of shade, resulting in considerably lower mean radiant temperatures, has more influence on the thermal comfort expressed in PET than the decrease of the wind speed. Moreover, trees increase the quality of the public space, also due to other benefits, not included in this study yet, like absorption of rainwater and $\mathrm{CO}_{2}$ and other air pollutants uptake.

Isolated trees and even rows of trees have a rather small impact on the decrease of air temperatures, and thus, apparently a limited potential for mitigating air temperatures of the urban heat island. Consequently the possibility to improve energy efficiency of buildings by decreasing heat loads is limited. However, the lower surface temperatures of roofs and façades caused by the vegetation will contribute to lower cooling loads (Akbari et al., 2001). 
Only the implementation of city-wide changes (from groups of trees to large-scale green space interventions), encouraged by modified building codes and citizens' initiatives, could promote a greener (well distributed vegetation in) São Paulo and mitigation of the urban heat island. For this purpose, even in the $21^{\text {st }}$ century, vegetation remains an irreplaceable urban element. Hence, it is possible, nowadays, due to technological advance to access, to analyse and better understand the impacts of vegetation with the aid of tools like ENVI-met.

\section{Planned Future Work}

Future studies include research on different species of local urban street trees, on the importance of tree height, type of tree canopies, leaf area index (LAI) and leaf area density (LAD). Another aim is to adapt the standard ENVI-met plant database to a local plant database. Moreover, the climatically strategically positioning and grouping of trees will be studied.

In future work, other types of urban areas such as squares will be studied as well as different types of parks. In addition, the results of the questionnaire surveys on subjective perception of the thermal environment will be part of the thermal comfort studies.

Since the boundary conditions of the ENVI-met model can hardly be defined correctly based on field measurements, investigations on corrections and nesting with the meso-scale model RAMS (Freitas et al., 2007) has been initialized. Forcing the ENVI-met model may become necessary in future steps of the work process.

To calibrate the model for the conditions of the measurements we are trying to overcome the missing impact of heat storage by allocating materials with increased thermal mass around the buildings on the sidewalks according to a method proposed by Johansson (2006).

\section{ACKNOWLEDGEMENTS}

This research was supported by Holcim Foundation for Sustainable Construction (J. Spangenberg), Fundação de Amparo à Pesquisa do Estado de São Paulo - FAPESP (P. Shinzato) and Swedish International Development Cooperation Agency - Sida (E. Johansson). The authors are grateful to Labaut staff, University of São Paulo, for their assistance in the field measurements and to IAG - Institute of Astronomy, Geophysics and Atmospheric Sciences, University of São Paulo for assistance with the simulations. 


\section{REFERENCES}

AKBARI, H.; POMERANTZ, M.; TAHA, H. Cool surfaces and shade trees to reduce energy use and improve air quality in urban areas. Solar Energy, Tampa, vol. 70, n. 3, p. 295-310, 2001.

ALI-TOUDERT, F.; MAYER, H. Thermal comfort in urban streets with trees under hot summer conditions. In: PLEA 2005 - Passive and Low Energy Architecture, 2005, Beirut. Proceedings PLEA 2005 - Passive and Low Energy Architecture, Beirut: PLEA International, 2005, p. 699-704.

ALI-TOUDERT, F.; MAYER, H. Effects of asymmetry, galleries, overhanging façades and vegetation on thermal comfort in urban street canyons. Solar Energy, Tampa, vol. 81, p. 742-754, 2007.

BRUSE, M. ENVI-met v. 3.0. Available at: <http://www.envi-met.com>. Accessed 1 July 2007.

CHATZIDIMITRIOU, A.; CHRISSOMALLIDOU, N.; YANNAS, S. Microclimate modifications of an urban street in northern Greece. In: PLEA 2005 - Passive and Low Energy Architecture, 2005, Beirut. Proceedings PLEA 2005 - Passive and Low Energy Architecture, Beirut: PLEA International, 2005, p. 689-694.

DUARTE, D.; SOUZA, T. Urban Occupation Patterns and Microclimates in São Paulo Brazil. In: SB 2005. Sustainable Building, 2005, Tokyo. The 2005 World Sustainable Building Conference, 2005.

EMMANUEL, M. R. An Urban Approach to Climate-Sensitive Design - Strategies for the Tropics. New York, Spon Press, 2005.

FREITAS, E. D.; ROZOFF, C. M.; COTTON W. R.; SILVA DIAS, P. L. Interactions of an urban heat island and sea-breeze circulations during winter over the metropolitan area of São Paulo, Brazil. Boundary-Layer Meteorology, Dordrecht, vol. 122, p. 43-65, 2007.

HÖPPE, P. The physiological equivalent temperature - a universal index for the biometeorological assessment of the thermal environment. International Journal of Biometeorology , Dordrecht, vol. 43, p. 71-75, 1999. 
IBGE. Censos Demográficos, Instituto Brasileiro de Geografia e Estatística (IBGE), 2000.

JOHANSSON, E. Urban design and outdoor thermal comfort in warm climates studies in Fez and Colombo, 2006. Thesis (PhD in architecture), Housing Development \& Management, Lund University, Lund, Sweden, 2006.

JUSUF, S. K.; HIEN, W. K.; LA WIN, A. A.; THU, H. K.; NEGARA, T. S.; XUCHAO, W. Study on effect of greenery in campus area. In: PLEA 2006 - Passive and Low Energy Architecture, 2006, Geneva. Proceedings PLEA 2006 - Passive and Low Energy Architecture, Geneva: PLEA International, 2006, vol. I, p. 483-488.

LABAUT. Sustainable Urban Spaces. Intermediate report: context studies and the strategy for environmental/ sustainable urban design. Colaboração Internacional Brasil-UK. Laboratory of Comfort and Energy Studies - LABAUT, FAUUSP. São Paulo, 2006. (To be published)

MEYER, R. P. M.; GROSTEIN, M. D.; BIDERMAN, C. São Paulo Metrópole. Sao Paulo: EDUSP, 2004.

MONTEIRO, L. M. AND ALUCCI, M. P. Calibration of outdoor thermal comfort models. In: PLEA 2006 - Passive and Low Energy Architecture, 2006, Geneva. Proceedings PLEA 2006 - Passive and Low Energy Architecture, Geneva: PLEA International, 2006, vol. I, p. $515-522$

OKE, T. R. The micrometeorology of the urban forest. Phil. Trans. Royal Society London, London, vol. B324, p. 335-349, 1989.

ROMERO, S. Destination: São Paulo. Metropolis Magazine, October 2000. Available at: $<$ http://www.metropolismag.com/html/content 1000/sao.htm>. Accessed 1 July 2007.

SHASHUA-BAR, L.; HOFFMAN, M. E. Quantitative evaluation of passive cooling of the UCL microclimate in hot regions in summer, case study: urban streets and courtyards with trees. Building and Environment, Oxford, vol. 39, p. 1087-1099, 2004. 
SPANGENBERG, J. Improvement of Urban Climate in Tropical Metropolis - A case study in Maracanãl Rio de Janeiro, Thesis (Master in architecture), University of Applied Sciences, Cologne, Germany, 2004. Available at: < http://www.basis-id.de/science $>$. Acessed 3 March 2008.

SPANGENBERG, J.; SHINZATO, P.; JOHANSSON, E.; DUARTE, D. (2007). The Impact of Urban Vegetation on Microclimate in Hot Humid São Paulo, In: PLEA 2007 - Passive andLow Energy Architecture. 2007, Singapure. Proceedings PLEA 2007 - Passive and Low Energy Architecture, Singapure: PLEA International, 2007.

SÃO PAULO (cidade). Secretaria do Verde e do Meio Ambiente - SVMA. Atlas ambiental de São Paulo, Prefeitura da Cidade de São Paulo, 2004.

TAHA, H. Urban climates and heat islands: albedo, evapotranspiration, and anthropogenic heat. Energy and Buildings, Oxford, vol. 25, p. 99-103, 1997.

UWYO. Soundings. Available at: <http://weather.uwyo.edu/upperair/sounding.html>. Accessed 1 July 2007.

YU, C; HIEN, W. N. Thermal benefits of city parks. Energy and Buildings, Oxford, vol. 38, p. 105-120, 2006. 